\title{
HISTORIA HISTORIOGRAFII W PRAKTYCE DYDAKTYCZNE] - PRZYKŁAD POZNAŃSKI
}

Tomasz FALKOWSKI

\section{ABSTRACT}

\section{HISTORIOGRAPHY IN THE HIGHER EDUCATION - THE POSNANIAN SCHOOL EXAMPLE}

In the paper I resume some problems concerning the teaching of historiography at the Faculties of History in Poland. Having thirty hours to present historiography from Antiquity to Present Times, the Polish scholars must answer to the following questions: is it necessary to discuss with students every stage of the development of history, or maybe would it be better to focus on the twentieth century historical schools and tendencies? In what proportion the national history should be included in the universal one? Based on my personal teaching experience, I try to show how that kind of dilemas could be resolved.

\section{KEYWORDS:}


Na Uniwersytecie im. Adama Mickiewicza w Poznaniu, w Instytucie Historii, historia historiografii nauczana jest w ramach trzydziestogodzinnych zajęć o charakterze konwersatoryjnym, przeznaczonych dla studentów drugiego roku pierwszego stopnia studiów historycznych.

Tego rodzaju formuła programowa stawia przed prowadzącym określone wyzwania, przede wszystkim związane z selekcją przekazywanego materiału. Jak doskonale wiadomo, historiografia - pod taką czy inną postacią - istniała w każdej epoce historycznej, towarzysząc dziejom ludzkim od czasów antycznych po dzień dzisiejszy; ponadto rozwijała się zarówno w wymiarze powszechnym, jak i naszym lokalnym, polskim. W konsekwencji, stając w obliczu tak obszernej dziedziny przedmiotowej i mając do dyspozycji jedynie trzydzieści godzin dydaktycznych, wybór elementów wiedzy z tego zakresu siłą rzeczy musi być daleko idący, wręcz skrajny, ale o tyle też gruntowniej przemyślany.

Pierwsze pytanie domagające się odpowiedzi dotyczy tego, czy w ramach omawianych zajęć należy rozpoczynać od analizy historiografii w dawniejszych epokach, śledząc jej losy w starożytnej Grecji i starożytnym Rzymie, wspominając o księgach historycznych Starego Testamentu jako najważniejszym trzonie historiografii hebrajskiej, przechodząc następnie do narodzin chrześcijańskiej myśli historycznej itd., czy raczej - ze względu na ograniczenia czasowe - skupić się na współczesnych badaniach historycznych i ich wielonurtowości, wychodząc na przykład od dziewiętnastowiecznego historyzmu i pozytywizmu, by następnie szerzej omówić najważniejsze szkoły i modele uprawiania historii, które pojawiły się i rozwijały w XX wieku (pierwsze pokolenie szkoły Annales, historia globalna, historia serialna, New Economic History, mikrohistoria...) ? Za wyborem drugiej opcji przemawiają co najmniej dwa argumenty. Po pierwsze, wydaje się, że z podstawowymi postaciami i dziełami wchodzącymi w skład historiografii antycznej i średniowiecznej studenci spotykają się podczas zajęć kursowych poświęconych tym właśnie epokom, co wynika między innymi z tego, że zazwyczaj prace te są równocześnie najważniejszymi źródłami na temat omawianych na tych kursach zjawisk. Herodot jest historykiem greckim, zarazem jednak - z perspektywy wiedzotwórczej - autorem podstawowego źródła do problematyki wojen grecko-perskich. Podobnie sprawa wygląda z Tukidydesem i wojną peloponeską, Tytusem Liwiuszem i pierwszymi stuleciami istnienia Rzymu itd. W rezultacie student nabywa wówczas, w sposób niejako pośredni, pewnej wiedzy ściśle należącej do historii historiografii. Drugi argument wspierający przekonanie o konieczności położenia większego nacisku na historiografię współczesną wiąże się 
z następującą ideą: najważniejsze książki historyczne pisane w dzisiejszych czasach w jakiś sposób odnoszą się do takich czy innych dwudziestowiecznych nurtów pisarstwa historycznego i bez znajomości tych ostatnich dużo trudniej jest zrozumieć zastosowane w nich podejście, interpretacyjną wykładnię, język wywodu i inne ich aspekty. Kiedy na przykład sięgamy po wydaną niedawno na rynku polskim trzytomową Historię ciała ' łatwiej uchwycić jej specyfikę, mając świadomość, w jaki sposób i w jakich myślowych warunkach coś takiego jak ciało stało się przedmiotem badań historycznych, a także na czym polegał kilkadziesiąt lat temu zwrot części historyków ku antropologii, upatrujących w niej nowego źródła inspiracji.

Nie oznacza to, rzecz jasna, że rozpoczynanie zajęć z historii historiografii od dawniejszych epok jest bezzasadne. Wręcz przeciwnie, nietrudno znaleźć przesłanki przemawiające na korzyść takiego właśnie rozwiązania. Z jednej strony, niejednokrotnie zdarzyło mi się podczas rozmowy zaliczeniowej, że przepytywana osoba miała problemy z najbardziej podstawowymi kwestiami odnoszącymi się do antyku czy średniowiecza, nie potrafiąc na przykład poprawnie usytuować „ojców historiografii” zarówno w czasie, jak i w ich kontekście kulturowym. W tego rodzaju przypadkach zastosowanie klasycznej maksymy repetitio est mater studiorum wydaje się jak najbardziej wskazane. Z drugiej strony, wraz z posuwaniem się w czasie, z przechodzeniem od jednej epoki do drugiej, związek między elementem historiograficznym a źródłowym danych prac historycznych - oczywiście z punktu widzenia praktyki dydaktycznej - staje się coraz luźniejszy, coraz mniej bezpośredni. Mówiąc konkretniej: na zajęciach ze starożytności analizuje się historyczne dzieło Herodota jako podstawowe źródło do dziejów wojen grecko-perskich, trudno natomiast na ćwiczeniach z historii nowożytnej zrobić podobnie z Rozważaniami nad pierwszym dziesięcioksięgiem historii Rzymu Liwiusza Machiavellego, to znaczy analizować tę pracę jako źródło na temat tego, o czym ona opowiada (choć oczywiście można ją potraktować w ten sposób w odniesieniu do innego problemu, a mianowicie do pytania: jak myślano w renesansie o starożytnym Rzymie? Wydaje się jednak, że takie podejście bliższe jest właśnie specjalistycznym badaniom z zakresu historii historiografii niż ograniczonym czasowo zajęciom z XVI wieku). W efekcie można ostrożnie założyć, że drogi między dydaktycznie skrojonym obrazem dziejów od czasów najdawniejszych po dzień dzisiejszy - obrazem wykładanym podczas trzyletnich studiów historycznych - a historią historiografii (czy ściślej: jej elementami) dość szybko się rozchodzą. Wzmacnia to tym samym przekonanie, że na zajęciach $\mathrm{z}$ tej ostatniej nie należałoby się ograniczać do pisarstwa historycznego powstałego w ostatnich dwóch stuleciach.

1 Historia ciała, red. A. Corbin, J.-J. Courine i G. Vigarello, 3 t., Gdańsk 2011-2014. 
Dodatkową trudnością - i to w ramach obu możliwych opcji - jest kwestia włączenia do przekazywanego materiału historiografii polskiej. W pierwszym przypadku, gdy decydujemy się na przedstawienie rozwoju nauki spod znaku Klio od starożytności po czasy współczesne, pytanie, na ile uwzględnić twórczość rodzimych historyków w całościowym planie, pojawia się bardzo szybko, bo już na zajęciach dotyczących przekazów średniowiecznych. W przypadku drugim, gdy ograniczamy się do nakreślenia panoramy historiografii współczesnej, wyłania się kwestia proporcji między historiografią polską a historiografią obcą.

Czy jest możliwe sensowne połączenie obu dydaktycznych perspektyw, to znaczy zachowanie zarówno wykładu z rozwoju historiografii poprzez poszczególne epoki, jak i uwypuklenie jej dziejów najnowszych, aby dostarczyć studentom wiedzę pozwalającą im sprawniej poruszać się wśród dzisiejszej rozmaitości historiograficznego świata? I czy jest przy tym jeszcze możliwe znaleźć miejsce dla twórczości polskich historyków? Tego typu karkołomną próbę podejmuję od kilku lat na prowadzonych przez siebie zajęciach ze studentami drugiego roku.

Wygląda to w sposób następujący. Zajęcia przebiegają dwutorowo. Co drugie spotkanie przeznaczone zostaje na omówienie - w porządku chronologicznym historiografii w danej epoce. W ramach tej pierwszej ścieżki za przewodnik służy nam znana książka Jerzego Topolskiego Od Achillesa do Béatrice de Planissolles. Zarys historii historiografii ${ }^{2}$.Już sama jej struktura bardzo dobrze wpisuje się w harmonogram spotkań. Topolski podzielił swój skrypt na osiem rozdziałów, w których syntetycznie przedstawia losy historiografii na przestrzeni całych dziejów. Mając do dyspozycji piętnaście dwugodzinnych spotkań w semestrze, na siedmiu z nich - w efekcie połączenia drugiego i trzeciego rozdziału książki w jedną całość, ponieważ oba dotyczą epoki średniowiecznej - podążamy za wywodem autora, traktując go oczywiście jako bazę czy punkt wyjścia do bardziej szczegółowej dyskusji na samych zajęciach. Ponadto niewątpliwą zaletą skryptu Topolskiego jest połączenie w nim kilku istotnych warstw dających się wyróżnić w głównym przedmiocie konwersatorium, czyli w historiografii: obok najważniejszych dzieł i postaci tworzących jej dzieje poznański historyk omawia bowiem przemiany, które w różnych czasach stały się udziałem najistotniejszych składowych myślenia i pisarstwa historycznego, a więc idei czasu, przyczynowości, wizji rzeczywistości historycznej oraz historyczności człowieka, tego, kto dla historyków z danej epoki był podmiotem dziejotwórczym itd. Studenci, po lekturze każdego z rozdziałów, mają istotny punkt zaczepienia do dyskusji nad podstawowymi wymiarami każdej historiografii w ich tymczasowej tożsamości, epokowym wykroju,

2 J. Topolski, Od Achillesa do Béatrice de Planissolles. Zarys historii historiografii, Warszawa 1998. 
dzięki czemu podczas samych zajęć próbujemy je wyłącznie rozwinąć, ewentualnie uszczegółowić czy bardziej skonkretyzować. Dodatkowo, poczynając od średniowiecza, staram się przynajmniej zasygnalizować sposoby, w jakie prace historyków polskich należały - przede wszystkim w wyżej wymienionych wymiarach - do europejskiego nurtu pisarstwa historycznego.

Druga ścieżka, realizowana naprzemiennie z pierwszą, a więc również w rytmie codwutygodniowym, skupia się na historiografii współczesnej. Przy czym w odróżnieniu od zajęć poświęconych dawniejszym epokom tutaj nie podążamy za żadnym istniejącym już wywodem jakiegoś jednego autora, lecz czytamy fragmenty monografii powstałych w XX wieku i na początku wieku XXI. Ponieważ na jedno spotkanie przypada jedna monografia, w całym semestrze omawiamy siedem książek. Kryteriów doboru tych lektur jest kilka. Po pierwsze, ważne, aby dana monografia była reprezentatywna dla jednej spośród najważniejszych szkół czy nurtów historiograficznych, jakie pojawiły się w minionym stuleciu (lub na początku obecnego stulecia). Drugim kryterium ściśle związanym z pierwszym - jest istnienie interdyscyplinarnego mariażu między historią a innymi naukami humanistycznymi czy społecznymi. Jak wiadomo, wiele najważniejszych propozycji czy modeli współczesnego pisarstwa historycznego narodziło się w efekcie swoistego otwarcia historiografii na inspiracje plynące z innych dyscyplin. Po trzecie, ponieważ przedmiot nauczany jest na różnych specjalizacjach studiów historycznych (od mediewistyki poprzez wojskowość aż po politykę i media w dziejach), należy przynajmniej częściowo uwzględnić tematykę wyselekcjonowanych monografii pod tym właśnie kątem. Stąd zresztą lista lektur nie powinna być i nie jest stała. Wreszcie niebagatelną i nieuniknioną rolę w omawianym wyborze odgrywają z pewnością indywidualne preferencje, idiosynkrazje i zainteresowania prowadzącego.

Nie zamierzam w tym miejscu wymieniać wszystkich monografii, które omawiałem wspólnie ze studentami na zajęciach, ale tytułem przykładu wspomnę o kilku z nich, aby zasygnalizować logikę ich selekcji zgodnie z podanymi wcześniej kryteriami. Jako klasyczne przykłady nurtu mikrohistorii czytamy Ser i robaki Carlo Giznburga ${ }^{3}$ bądź Montaillou. Wioskę heretyków Emmanuela Le Roy Laduriego ${ }^{4}$. Komentarz do takiego a nie innego akurat wyboru wydaje się tutaj zbyteczny. Podobnie jest w przypadku historii globalnej i propozycji lektury fragmentów z Morza Śródziemnego Fernanda Braudela ${ }^{5}$, gdyż dzieło to stanowi chyba najgłośniejszy przykład realizacji tego modelu badań historycznych. W ramach specjalizacji mediewistycznej pojawia się książka

\footnotetext{
C. Ginzburg, Ser i robaki. Wizja świata pewnego mlynarza z XVI wieku, Warszawa 1989.

E. Le Roy Ladurie, Montaillou. Wioska heretyków 1294-1324, Warszawa 2014.

F. Braudel, Morze Śródziemne i świat śródziemnomorski w epoce Filipa II, t. I-II, Warszawa 2004.
} 
Georges'a Duby’ego Bitwa pod Bouvines ${ }^{6}$, która - po pierwsze - jest przykładem udanego połączenia historii i etnologii, po drugie - odnosi się oczywiście do zjawiska średniowiecznego, po trzecie - ukazuje alternatywne wobec pozytywistycznego podejście do wydarzenia historycznego. Z kolei studenci ze specjalizacji wojskoznawczej zapoznają się z niedawno opublikowaną pracą Sönka Neitzla i Haralda Welzera Żotnierze. Protokoły walk, zabijania i umierania ${ }^{7}$, będącą egzemplifikacją współpracy między historią a psychologia społeczną, co ma w zamyśle pomóc pełniej zrozumieć problem przemocy i brutalizacji ludzkich zachowań w warunkach wojennych (w tym przypadku w warunkach drugiej wojny światowej). W wyjątkowych przypadkach głównym czynnikiem wyboru danej lektury może być również aktualność czy też odkrycie zapoznanej przez historyków problematyki. Tak stało się w kontekście omawianych zajęć z książką Macieja Zaremby Bielawskiego Higieniści. Z dziejów eugeniki ${ }^{8}$. Mimo że jej autorem nie jest zawodowy historyk, to jednak ze względu na swą rzetelność, szerokie ujęcie ważnego zjawiska historycznego, jakim była eugenika, a także z uwagi na demontaż wielu funkcjonujących stereotypów, praca ta - jak się wydaje - godna jest refleksji na historii historiografii. Poza tym doskonale pokazuje, w jaki sposób wiedza na temat przeszłości jakiegoś fenomenu pozwala lepiej odczytać cały zbiór współczesnych praktyk i dyskursów; a równocześnie uwidacznia, że pisarstwo historyczne spełnia ważne funkcje społeczne, walcząc ze zniekształconymi obrazami danych fragmentów minionej rzeczywistości. Czasami również studenci wychodzą z inicjatywą przyjrzenia się jakiejś konkretnej monografii. I jeśli z takiego czy innego względu można uznać ją za istotną dla współczesnej historiografii, nie ma przeszkód, dla których należałoby im odmówić. Dwa lata temu jedna z grup zaproponowała Korzenie totalitaryzmu Hannah Arendt ${ }^{9}$. Jako że jest to praca dla humanistyki już dziś klasyczna, a jednocześnie łączy perspektywę historyczną z perspektywą filozoficzną, jak najbardziej przychyliłem się do tej prośby.

Zdaję sobie oczywiście sprawę, że każdy wybór w zakresie prac istotnych dla współczesnej historiografii będzie dyskusyjny. Powyższa propozycja, starająca się wybrnąć z pewnych dylematów stojących przed nauczycielem akademickim prowadzącym zajęcia $\mathrm{z}$ historii historiografii, jest tylko jednym z możliwych rozwiązań dydaktycznych, któremu z pewnością daleko do doskonałości.

G. Duby, Bitwa pod Bouvines, Warszawa 1988.

S. Neitzel, H. Welzer, Żotnierze. Protokoty walk, zabijania i umierania, Warszawa 2014.

M. Zaremba Bielawski, Higieniści. Z dziejów eugeniki, Wołowiec 2014.

9 H. Arendt, Korzenie totalitaryzmu, Warszawa 2014. 